\title{
IAMJ
}

INTERNATIONAL

AYURVEDIC

MEDICAL JOURNAL

\section{A COMPARATIVE CLINICAL STUDY TO EVALUATE THE EFFECT OF VRIKSHAMLA TWAK KASHAYA AND DASHAMOOLA KASHAYA IN UDAVARTHINI YONIVYAPAT}

\author{
Sahana G1, Shivale Digambar $P^{2}$, Kavitha B.K ${ }^{3}$, Manju Parvathy ${ }^{4}$ \\ ${ }^{1} 3^{\text {rd }}$ Year PG scholar, Dept. of Prasooti Tantra and Stree Roga, Alva's Ayurveda Medical College \& Hospital, \\ Moodbidri, Karnataka, India \\ ${ }^{2}$ Professor, Dept. of Prasooti Tantra and Stree Roga, Alva's Ayurveda Medical College \& Hospital, Moodbidri, \\ Karnataka, India \\ ${ }^{3}$ Associate Professor, Dept. of Prasooti Tantra and Stree Roga, Alva's Ayurveda Medical College \& Hospital, \\ Moodbidri, Karnataka, India \\ ${ }^{4}$ Assistant professor, Dept. of Prasooti Tantra and Stree Roga, Alva's Ayurveda medical college \& Hospital, \\ Moodbidri, Karnataka, India
}

Corresponding Author: drsahanag28@gmail.com

\section{https://doi.org/10.46607/iamj0309102021}

(Published Online: October 2021)

Open Access

(C) International Ayurvedic Medical Journal, India 2021

Article Received: 22/09//2021 - Peer Reviewed: 06/10/2021 - Accepted for Publication: 07/10/2021

\section{Check for updates}

\begin{abstract}
Menstruation is a physiological, natural event in the reproductive stage of the female. Due to a sedentary lifestyle and lack of self-care, stress, untimely food and other factors, many gynaecological problems occur and one of the most common among them is Dysmenorrhea. Painful menstruation is the most common cause which disturbs the mental state of the woman also affecting her day to day activities during the cycle. Pain is the Pratyatma Lakshana of Vata vikruti mentioned in Ayurveda. Artava Nishkramana is the normal function of Apana vayu which moves in Pratiloma gati and obstructs the pathway of Artava. In our Classics, most of the gynaecological problems are discussed under Yonivyapat. Udavartini Yonivyapat can be co-related and defined as painful menstruation i.e. Dysmenorrhea. Considering the prevalence of dysmenorrhea in the present era, the trial drug Vrikshamla
\end{abstract}


twak kashaya which possess the properties such as Shoolprashamana and Vatahara was selected to evaluate its effect in the management of Udavartini yonivyapat. Objectives: To compare and evaluate the effect of Vrikshamla Twak kashaya and Dashamoola kashaya in Udavarthini yonivyapat w.r.s primary dysmenorrhea. Methodology: This research work was a randomized comparative clinical study of 40 patients suffering from symptoms of Udavartini Yonivyapat, who were randomly selected and categorized into 2 groups of 20 patients each. Group A was treated with Vrikshamla Twak kashaya and group B with Dashamoola Kashaya. Both Kashayas were given in Apanakaala (before food) with Sukhoshna Jala as Anupana. Duration of Treatment: 10 days (Starting 7days before the commencement of cycle till 3rd day of the menstrual cycle) for 3 consecutive cycles. Results and Interpretation- Both the groups showed statistically significant results. Statistically, there was no significant difference between the groups. Conclusion: Both Vrikshamla Twak kashaya and Dashamoola Kashaya had an equal effect in treating Udavartini Yonivyapat.

Keywords: Udavartini, Dysmenorrhea, Vrikshamla Twak Kashaya, Dashamoola kashaya.

\section{INTRODUCTION}

Dysmenorrhea or painful menstruation is the commonest complaint of the woman nowadays that which is increasing cycle to cycle with increased medications too into the body. It takes the definition as, the painful menstruation of sufficient magnitude so as to capacitate day-to-day activities ${ }^{1}$. There are 2 types of dysmenorrhea - a) Primary dysmenorrhea- without any pelvic pathology and b) Secondary dysmenorrhea- with pelvic pathology ${ }^{2}$ This is more common in women between the ages of 18-24 years. The study says that Dysmenorrhea is more in unmarried than in married women $(61 \% \mathrm{v} / \mathrm{s} 51 \%)^{3}$. In India, incidence and prevalence show the report as $33.5 \%$ and $87.8 \%$ respectively. The treatment for this condition is still unsatisfactory in conventional medicine, although non-steroidal anti-inflammatory drugs are tolerated well and seen leaving behind the side effects ${ }^{4}$. According to our classics "Na hi Vaatadrite Shoolam" that which means pain is the indication of Vata vikriti and Apana vata is the main culprit in all gynaecological disorders. Normal menstruation is the function of Apanavata, so painful menstruation is considered as Apanavatadushti ${ }^{5}$.

In Udavartini Yonivyapat due to Prathiloma Gati of Apanavayu because of Swaprakopa Nidhanas like Vataprakopa Ahara vihara and Vegadarana, it leads to Rajah krichrata or even Vyana avruta apana causes Margavarodha or even Upalepa of Arthava vaha srothas which is caused by Kapha Vardhaka Ahara
Vihara that which creates Avarodha to Gati of Apanavayu resulting in painful menstruation.

Keeping this into consideration and as per treatment principles of Udavartini study has been done to compare the effect of Vrikshamla Twak kashaya ${ }^{6}$ and Dashamoola Kashaya ${ }^{7}$ in the management of Udavartini Yonivyapat.

\section{MATERIALS AND METHODS}

Collection of Sources: 40 samples were selected randomly from OPD of PTSR of Alva's Ayurveda Hospital, Moodbidri, Medical camps and other referrals, irrespective of their religion, economic status \& occupation.

Study Design: A randomized comparative clinical study

Collection and Preparation of Drug: Raw drugs were identified and collected from the local market and Kashaya was prepared at Alva's pharmacy, Mijar

$>$ Method of Data Collection:

a) Selection of Subjects: Patients presenting with the symptoms of Udavarthini Yonivyapat fulfilling the inclusion criteria will be selected for the study.

- Sample size: 40

- Grouping: 2 arms (A \& B)

- Number: 20 in each arm

- Study design: A randomized comparative clinical study

- Blinding: single-blind 
- Method sampling: lottery method

b) Diagnostic Criteria:

Patients fulfilling any of the following diagnostic criteria will be selected for the study.

1) Painful menstruation begins with the onset of menstruation and lasts for 1 to 2 days.

2) Painful menstruation is associated with Pain in the suprapubic region, lower abdomen and low backache which radiates to the thighs

3) Painful menstruation is associated with symptoms like nausea, vomiting, loose stools, fatigue, constipation, giddiness and headache.

c) Inclusion Criteria:

1) Patients fulfilling the diagnostic criteria

2) The age group between 16-25 years
3) $\mathrm{H} / \mathrm{O}$ painful menstruation for at least 3 consecutive menstrual cycles

4) patients with regular menstrual cycles

d) Exclusion Criteria:

1) Cases of secondary dysmenorrhea with pelvic pathologies like ovarian cyst, Fibroid uterus and Endometriosis.

2) Patients on hormonal therapy.

3) Patients with vaginal atresia, cervical stenosis and Retroverted-uterus.

4) Patients with systemic diseases.

5) Patient with IUCD.

e) Interventions:

Treatment was started 7 days before expected menstruation and was continued up to another 3 days for 2 consecutive cycles.

Table 1:

\begin{tabular}{|l|l|l|l|l|l|}
\hline GROUP & SAMPLE & YOGA & DOSE & TIME OF ADMINISTRATION & ANUPANA \\
\hline A & 20 & Vrikshamla Twak kashaya & $50 \mathrm{ml}$ & Before food, BD & Lukewarm water \\
\hline B & 20 & Dashamoola kashaya & $50 \mathrm{ml}$ & Before food, BD & Lukewarm Water \\
\hline
\end{tabular}

Group A - Given with Vrikshamla Twak kashaya 50ml BD with an equal amount of lukewarm water.

Group B - Given with Dashamoola kashaya $50 \mathrm{ml}$ BD with an equal amount of lukewarm water

f) Observation Period:

The Total Duration of Treatment: 3 months

Treatment Period: 10 days

Days of Assessment: $4^{\text {th }}$ day of each menstrual cycle for 2 consecutive days.

Follow up: $4^{\text {th }}$ day of $3^{\text {rd }}$ cycle.

g) Assessment Criteria:
1) The intensity of the pain

2) Duration of the pain

3) Site of the pain-Lower abdomen, Low back, Pain radiating to the thigh

4) Associated complaints such as-Nausea, Vomiting, Headache, Anorexia, Fatigue and loose stools

Pain criteria were assessed using VAS

These parameters were graded, and scores are given accordingly

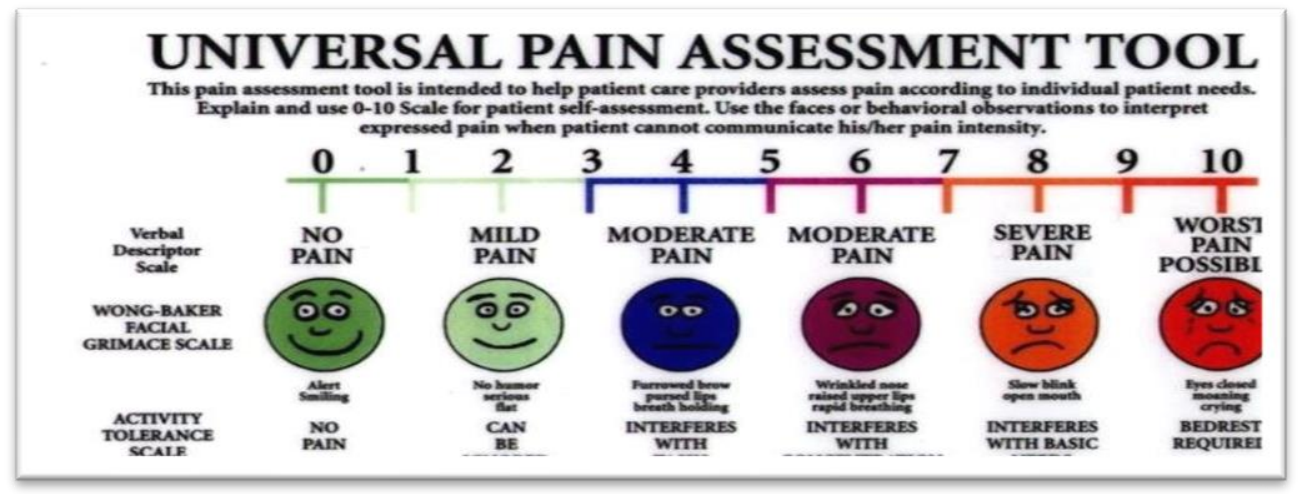


1. No Pain $-0 \quad$ - Grade -0

2. Mild pain $-1-3 \quad$ - Grade - 1

3. Moderate pain - 4-6 - Grade - 2

4. Severe pain $-7-10 \quad$ - Grade -3

Table 2:

\begin{tabular}{|c|c|c|c|c|}
\hline Assessment Criteria & Grade 0 & Grade 1 & Grade 2 & Grade 3 \\
\hline Intensity of pain & $\begin{array}{l}0 \text { (No pain) } \\
\text { Menstruation is } \\
\text { not painful and } \\
\text { daily activity is } \\
\text { unaffected }\end{array}$ & $\begin{array}{l}1 \text { to } 3 \text { (Mild pain) } \\
\text { Menstruation is painful } \\
\text { but daily activity is not } \\
\text { affected }\end{array}$ & $\begin{array}{l}4-6 \text { (moderate pain) } \\
\text { Menstruation is pain- } \\
\text { ful and daily activity } \\
\text { is affected. An analge- } \\
\text { sic drug is needed. }\end{array}$ & $\begin{array}{l}7-10 \\
\text { (Severe pain) } \\
\text { Menstruation is so painful } \\
\text { that the patient is unable } \\
\text { to do even the routine } \\
\text { work and has to take an } \\
\text { analgesic, but without } \\
\text { much relief }\end{array}$ \\
\hline Duration of Pain & No pain & $\begin{array}{l}\text { Pain continues for up } \\
\text { to } 24 \mathrm{hrs} \text {. }\end{array}$ & $\begin{array}{l}\text { Pain continues for } 24 \\
\text { to }<48 \mathrm{hrs}\end{array}$ & $\begin{array}{l}\text { Pain continues for } 48 \\
\text { hours to }<72 \mathrm{hrs}\end{array}$ \\
\hline $\begin{array}{l}\text { Site of pain } \\
\text { (Lower Abdomen pain, } \\
\text { Back pain, Pain radiat- } \\
\text { ing to thighs) }\end{array}$ & No pain & $\begin{array}{l}\text { Presence of all } 3 \text { for } \\
\text { less than } 1 \mathrm{hr} \text { or any } 2 \\
\text { features for less than } \\
\text { 6hrs or any } 1 \text { feature } \\
\text { for less than } 12 \mathrm{~h}\end{array}$ & $\begin{array}{l}\text { Presence of all } 3 \text { for } \\
1-2 \mathrm{hrs} \text { or any two fea- } \\
\text { tures for } 612 \mathrm{hrs} \text { or any } \\
\text { one feature for more } \\
\text { than } 12 \mathrm{hrs}\end{array}$ & $\begin{array}{l}\text { Presence of all } 3 \text { for more } \\
\text { than } 2 \mathrm{hrs} \text { any two features } \\
\text { for } 12-24 \mathrm{hrs} \text { any } 1 \text { feature } \\
\text { for } 24 \mathrm{hrs}\end{array}$ \\
\hline $\begin{array}{l}\text { Associated com- } \\
\text { plaints (Nausea, vom- } \\
\text { iting, diarrhoea, head- } \\
\text { ache, irritability, con- } \\
\text { stipation, breast ten- } \\
\text { derness) }\end{array}$ & $\begin{array}{l}\text { No associated } \\
\text { complaints }\end{array}$ & $1-3$ complaints & 4-6 complaints & $>6$ complaints \\
\hline
\end{tabular}

Overall Assessment: The total effect of the therapy was assessed considering the overall improvement in signs and symptoms.

Marked Improvement: $76 \%-100 \%$ relief in the signs and symptoms

Moderate Improvement: $51 \%-75 \%$ relief in the signs and symptoms

Mild Improvement: $26 \%-50 \%$ relief in the signs and symptoms

Assessment of Total Effect of Therapy

Table 3: Comparative results of Group A and Group B

\begin{tabular}{|c|c|c|c|c|c|c|c|c|}
\hline \multirow[t]{2}{*}{ Parameters } & \multicolumn{2}{|c|}{ BT-AT Mean } & \multirow[t]{2}{*}{ d } & \multicolumn{2}{|c|}{$\%$ of relief } & \multicolumn{2}{|c|}{ Mann- Whitney U test } & \multirow[t]{2}{*}{ Remarks } \\
\hline & Group A & Group B & & Group A & Group B & t value & p-value & \\
\hline Intensity of pain & 3.35 & 2.650 & 0.7 & $49.6 \%$ & $35.8 \%$ & 456 & $=0.218$ & NS \\
\hline Duration of pain & 0.850 & 0.65 & 0.2 & $39.5 \%$ & $27.65 \%$ & 450 & $=0.283$ & NS \\
\hline Site of pain & 1.05 & 0.6 & 0.45 & $42 \%$ & $29.26 \%$ & 484 & $=0.046$ & SS \\
\hline Associated complaints & 0.55 & 0.70 & -0.15 & $42.3 \%$ & $45.16 \%$ & 380 & $=0.424$ & NS \\
\hline
\end{tabular}

Unchanged: Below $25 \%$ relief in the signs and symptoms

\section{Statistical analysis}

- Central tendencies and dispersions were measured using Mean, Median, Standard Deviation, Standard Error and Quartiles.

-Test of significance was done using Wilcoxon signed-rank test and Mann-Whitney U test. 
Table 4: The overall effect of Treatment in Group-A

\begin{tabular}{|l|l|l|l|}
\hline CLASS & GRADING & NO. OF Pts & PERCENTAGE \\
\hline$<25 \%$ & Unchanged & 2 & $10 \%$ \\
\hline $26-50 \%$ & Mild improvement & 2 & $10 \%$ \\
\hline $51-75 \%$ & Moderate improvement & 3 & $15 \%$ \\
\hline $76-100 \%$ & Marked improvement & 13 & $65 \%$ \\
\hline
\end{tabular}

Table 5: The overall effect of Treatment in Group-B

\begin{tabular}{|l|l|l|l|}
\hline CLASS & GRADING & NO. of Pts & PERCENTAGE \\
\hline$<25 \%$ & Unchanged & 2 & $10 \%$ \\
\hline $26-50 \%$ & Mild Improvement & 1 & $5 \%$ \\
\hline $51-75 \%$ & Moderate improvement & 6 & $30 \%$ \\
\hline $76-100 \%$ & Marked improvement & 11 & $55 \%$ \\
\hline
\end{tabular}

\section{DISCUSSION}

As Painful menstruation is the dominant feature in both Primary dysmenorrhea and Udavartini yonivyapat, Primary dysmenorrhea may be equated with Udavartini Yonivyapat in Ayurveda. Udavartini yonivyapath is termed so due to the movement of rajas in an upward direction. Here Vata gets vitiated due to Vegadharana, moves in Viloma gati pushing the rajas in an upward direction and discharges with great difficulty. Relief from the pain is obtained following menstruation. Here, Apana and Vyana Vayu are especially involved which may be aggravated due to indulgence in Vata Prakopaka Ahara-Vihara and Vegavarodha and thus becomes a vicious cycle. Artava is considered as Shuddha when menstruation is devoid of Arti, Pichchilata, Daha, and the flow is neither too less nor too more in quantity. Any variation from this normalcy causes different types of $\mathrm{Ar}$ thava vyapath and Yonivyapath.

Discussion on probable action of Vrikshamla Twak Kashaya

Vrikshamla Twak kashaya is the single drug formulation mentioned in Sahasrayoga under the context of Arthava shodana and Krichra arthava.

Based on Rasa, Guna, Veerya, Vipaka and Karma:

- The drug Vrikshamla Ttwak possess Kashaya Rasa, Madhura Vipaka and Ushna Veerya which acts on Vata vikriti.

- It is Deepana and also acts as Vata Prashamana, Vata Anulomaka and Shoolahara in action ${ }^{8}$
- Does Vata Anulomana and thus helps in Anuloma gati of Vata and Raja.

- This pacifies Vata and clears Kapha in the case of Upalepa of Arthava Vaha Srothas caused due to Kaphaja Aharas. Hence helps in the easy flow of menstruation

- Its chemical constituents: volkensoflavone, marelloflavone which acts as anti-inflammatory and analgesic in action.

Discussion on the probable mode of action of Dashamoola Kashaya

Dashamoola kashaya is mentioned under the context of Udavartini yonivyapt in Sha.sam.madyama and also mentioned in Sahasrayoga under the context of Kashaya yogas for Suthika and in Yogarathnakara under Vatavyadi Chikitsa, in Bhaishajya Rathnavali under the context of Kasa Rogadikara and also in Ashtanga Hridaya under the context of Annaswarupiya Adyaya.

KASHAYA: Though the term Dashamoola is described many times by Caraka, drugs of this group has been specified by Sushruta, which includes both Laghu and Bruhat Panchamoola. Charaka has included these ten drugs under Vatahara drugs, Shothahara Dashemani and Pancha-panchamoola.

$\checkmark$ Most of the drugs in Dashamoola have got Madhura \& Kashaya Rasa, Laghu Ruksha Guna, Ushna Veerya, Madhura Vipaka, which mainly act on Vata vikriti.

$\checkmark \quad$ Madhura Rasa, Laghu Guna and Madhura Vipa$k a$ help to pacify vitiated Vata, Kashaya rasa and 
Ushna Veerya does the action of Amapachana \& cleanses the Srotas.

$\checkmark$ Pharmacologically Dashamoola is having Analgesic, Anti-inflammatory, Antipyretic action which has been reported by gupta (1986) which in turn helps in reducing prostaglandin secretion.

$\checkmark$ Kantakari is anti-inflammatory in action, also used in constipation. Leaves are used locally to relieve pain.

$\checkmark$ Shalaparni had a relaxant effect on the smooth muscles of intestines of dog, rabbit and isolated rat Uterus according to the study $\checkmark$ Bilva contributes to its analgesic activity by the destruction of the mediators of inflammation such as 5-hydroxy tryptamine, bradykinin, histamine, prostaglandins etc. A significant resistance against mechanical pain indicates potent analgesic activity.

$\checkmark$ Dashamoola acts as anti-platelet potential and prostaglandin synthesis inhibition in turn it reduces the clots and pain during menstruation ${ }^{9}$.

Table 6:

\begin{tabular}{|l|l|l|l|}
\hline \multirow{2}{*}{ PARAMETERS } & \multicolumn{2}{|c|}{$\%$ OF RELIEF } & P-VALUE \\
\hline Intensity of pain & GROUP A & GROUP B & 0.218 (NS) \\
\hline Duration of pain & $49.6 \%$ & $35.8 \%$ & 0.283 (NS) \\
\hline Site of pain & $39.5 \%$ & $27.65 \%$ & $0.046(\mathrm{SS})$ \\
\hline Associated complaints & $42 \%$ & $29.26 \%$ & 0.424 (NS) \\
\hline Overall \% & $42.3 \%$ & $45.16 \%$ & \\
\hline
\end{tabular}

\section{CONCLUSION}

The aim of this study was to evaluate the effect of Vrikshamla Twak kashaya and Dashamoola Kashaya in Udavartini Yonivyapat. Both the Kashayas has got Vatanulomana properties that are found to be very effective in relieving the intensity, duration and site of pain and in associated complaints of irritability, headache, nausea, vomiting and diarrhoea. In comparison between the groups, both groups showed significant improvement in the management of signs and symptoms of Udavartini Yonivyapat. Both Vrikshamla Twak Kashaya and Dashamoola Kashaya were effective in the treatment of Udavartini Yonivyapat with a statistically highly significant result with $\mathrm{p}<0.001$. On comparison between 2 groups, there was no statistically significant difference in the effect of treatment p-value showing $(\mathrm{P}=>0.05)$.

Hence the null hypothesis $\mathrm{HO}$ is accepted i.e. $\mathrm{H} 0$ There is no significant difference between the effect of Vrikshamla Twak Kashaya and Dashamoola Kashaya in Udavartini yonivyapat.

\section{REFERENCES}

1. DC Dutta, Textbook of Gynaecology Including contraceptive, edited by Hiralal Konar, 7th edition, 2016, jaypee brothers' medical publishers (P) Ltd, New Delhi. pg. No -146.

2. Dutta DC, textbook of Gynecology, 4th ed. Kolkata: new central book agency; 2006 p. 168

3. Durain D. (2008). Women's health about cures. The difficulty with dysmenorrhrea,17, 44.Art.no.cd001751.DOI:10.1002/1465185.CD00175 1(PubMed)

4. Marjoribanks J, Ayeleke RO, Farquhar C, Proctor M. nonsteroidal anti-inflammatory drugs for dysmenorrhea. Reviews 2015, issue7.

5. Agnivesha, Caraka, Drudabala, Chakrapani Dutta, Acharya J.T D Caraka Samhitha with Ayurveda Dipika commentary. $1^{\text {st }}$ ed. Varanasi. Choukamba Prakashan:2009. Chikitsa sthana 30/115.

6. K. Nishteshwar RV. Sahasrayogam Text with English translation. Varanasi, India: Chowkhamba Sanskrit Series Office; 2008. Pg- 402

7. Arpana Jain et al: Clinical Study on Therapeutic Effect Of Dashamoola Ksheerapaka And Dhanvantari Taila Matra Basti In Udavartini Yonivyapad W.S.R To Dysmenorrhea. International Ayurvedic Medical 
Journal\{online\} 2020 \{cited December 2020\} Availa-

ble

from:

http://www.iamj.in/posts/images/upload/5232_5241.p

df

8. Sastry JLN. Dravyaguna Vijnana Vol 2. Varanasi, India: Chaukhambha Orientalia; 2010. Pg- 622

9. Reshma R. Parekar, Somesh S. Bolegave, Nirmala N. Rege. Experimental evaluation of analgesic, antiinflammatory and anti-platelet potential of Dashamoola. Journal of Ayurveda and Integrati. 2015;6(1):11-8.

\section{Source of Support: Nil \\ Conflict of Interest: None Declared}

How to cite this URL: Sahana G et al: A Comparative Clinical Study To Evaluate The Effect Of Vrik-Shamla Twak Kashaya And Dashamoola Kashaya In Udavarthini Yonivyapat. International Ayurvedic Medical Journal \{online\} 2021 \{cited October 2021\} Available from: http://www.iamj.in/posts/images/upload/2303_2309.pdf 